\title{
Berber Law by French Means: Customary Courts in the Moroccan Hinterlands, 1930-1956
}

\author{
KATHERINE E. HOFFMAN
}

Northwestern University

As the French conquered Muslim lands in their nineteenth- and early-twentieth-century quest for empire, they encountered multiple and sometimes mixed judicial systems among the native populations. In many places, legal codes were shaped by either fiqh, meaning Islamic law, one component of which is customary law, or by non-Islamic custom, or some combination of the two. ${ }^{1}$ To administer native justice in French colonies and protectorates,

Acknowledgments: Generous funding for this research was provided by a Charles Ryskamp Fellowship from the American Council of Learned Societies, a National Endowment for the Humanities Faculty Fellowship, a long-term fellowship from the American Institute for Maghrib Studies, a Northwestern University Faculty Research Grant, and an Institute for the Humanities Fellowship from the University of Illinois at Chicago. Mohamed Ouakrim, president of the Court of Taroudant Providence, and Ali Achfur, senior secretary at the Judicial Center, Igherm, generously allowed me to work with the original court dockets in Igherm and Taroudant. I wish to thank also Mina Alahyane and Hmad Laamrani for supplemental documentation, commentary, and helpful connections; Hafsa Oubou, Jenny Hall, and Devon Liddell for documentation; and Mohamed Mounib for provocative commentary on French Protectorate Berber policy. I am grateful to the fellows at the Camargo Foundation in Spring 2007, to archivist Anne-Sophie Cras at the Ministère des Affaires Etrangères archives in Nantes (CADN), and to Greta Austin, Joshua Cole, Clark Lombardi, and anonymous $\mathrm{CSSH}$ reviewers for comments and perspective. All translations from French are my own.

1 Debates around legal pluralism are summarized in Chris Fuller, "Legal Anthropology: Legal Pluralism and Legal Thought," Anthropology Today 10, 3 (1994): 9-12. Rather than presuming an objective distinction exists between Islamic and customary law, here I examine French attempts to identify, standardize, entextualize, and enforce such a distinction. Lawrence Rosen argues that Islamic law allows no specific place to custom as a source for judicial decision-making. See his "Islamic 'Case Law' and the Logic of Consequence," in June Starr and Jane F. Collier, eds., History and Power in the Study of Law (Ithaca: Cornell University Press, 1989), 302-19. However, Rosen argues, collections of amal legal commentary writings legitimized local custom in Islamic courts and were used in deliberation. On these commentaries, see Henry Toledano, Judicial Practice and Family Law in Morocco (New York: Columbia University Press, 1981). Preserving existing practices was understood to safeguard against the threat of chaos (fitna) that threatened society and communal life. On the relationship between Islamic and customary law in various Muslim societies, see John Bowen, Islam, Law and Equality in Indonesia: An 
officials sorted through this multiplicity in order to standardize procedures, principles, and punishments. The standardization of customary law codes, whether written or oral prior to submission to the makhzan (the central Moroccan government, lit. "storehouse") under the Protectorate, required that French officials both maintain pre-contact codes and create new institutions to administer and monitor them. Through new judicial bureaucracies, the French transformed indigenous law. Customary law was a "residual category"2 in the sense that it consisted of what remained after colonial powers ferreted out what they considered morally offensive and politically objectionable. Legal codification involved what Vincent calls "a compromise between those recognized as leading elements in indigenous societies and the colonial administrators who co-opted them."3 Yet customary law, "if understood as allowing local people to do their own cultural 'thing,' should also be understood to have been a carefully restricted fragment of 'tradition.",4 This tradition when manifest as customary law "implies that there is a different kind of law with which it can be contrasted," making customary law "the ongoing product of encounters between subordinate local political entities and dominant overarching ones.", In such encounters the distinction made between custom and law has long preoccupied legal historians, ${ }^{6}$ as well as anthropologists, colonial administrators, and importantly, lay people. Throughout French African colonies and protectorates, this distinction was key to the French usurpation of social institutions, ${ }^{7}$ as was true in British overseas territories as well. ${ }^{8}$

Anthropology of Public Reasoning (Cambridge: Cambridge University Press, 2003); Brinkley Messick, The Calligraphic State: Textual Domination and History in a Muslim Society (Berkeley: University of California, 1993); David Powers, Law, Society, and Culture in the Maghrib, 1300 1500 (Cambridge: Cambridge University Press, 2002); Lawrence Rosen, The Justice of Islam (New York: Oxford University Press, 2000), and Joseph Schacht, An Introduction to Islamic Law (Oxford: Oxford University Press, 1983). The negotiation of custom (adat or abangan in Indonesia) and Islamic law in the colonial South and Southeast Asian courts becomes even more complex. See specific cases in M. B. Hooker, Legal Pluralism: An Introduction to Colonial and Neo-Colonial Laws (Oxford: Clarendon Press, 1975), 111-16, and 266-78.

2 Sally Engle Merry, "Anthropology, Law and Transnational Processes," Annual Review of Anthropology 21 (1992): 364; and Sally Falk Moore, "History and the Redefinition of Custom on Kilimanjaro," in June Starr and Jane F. Collier, eds., History and Power in the Study of Law (Ithaca: Cornell University Press, 1989), 289.

3 Joan Vincent, "Contours of Change: Agrarian Law in Colonial Uganda, 1895-1962," in June Starr and Jane F. Collier, eds., History and Power in the Study of Law (Ithaca: Cornell University Press, 1989), 164.

4 Moore, "History," 293-94.

5 Ibid., 301.

${ }^{6}$ Sally Falk Moore, Law as Process: An Anthropological Approach (London: Routledge and Kegan Paul), 13.

${ }^{7}$ Rebecca Shereikis, "From Law to Custom: The Shifting Legal Status of Muslim Originaires in Kayes and Medine, 1903-13," Journal of African History 42 (2001): 261-83.

${ }^{8}$ Hooker, Legal Pluralism, 31. 
The transformation of native law under the French Protectorate of Morocco (1912-1956) was no exception. ${ }^{9}$ The Berber customary courts established in the 1930s were key sites of negotiation over legal reform and, more generally, native policy governing the rights and responsibilities of rural Moroccans. Certain aspects of allegedly Berber customary or Islamic law were retained because they suited the purposes of the Protectorate or were merely innocuous, while others were discouraged. Moreover, colonial-era Berber courts adopted French rules of procedure for both the hearing and documentation of disputes.

In this article, I consider the French administration of Berber customary law in Morocco as both policy and expressive practice, involving actors with conflicting interests, competing loyalties, and discursive styles, and multiple layers of spoken interpretation and written translation. Through the communicative site of the courtroom, actors contributed to the construction of a customary law that was neither identical to pre-Protectorate indigenous legal codes nor a wholesale adoption of Islamic law, as locally understood. Like other anthropologists of law under colonial regimes, I consider law here as a social process rather than a fixed code, even while the people about whom I am writing seem to have considered both "law" and "custom" to be immutable.

As Rosen has argued in regards to Islamic courts in Morocco, participants do not universally consider legal processes as entailing uniform penalties for identical infractions. Instead, both Moroccan judges and litigants may understand law as reflecting shared norms and ethics concerning the consequences of human action and the outcomes of judicial decisions. Consistency in Moroccan Islamic law lies not in the similarity of results in cases that appear to be similar, but in the constancy of the mode of analysis - of employing trustworthy witnesses, focusing on expert testimony, weighing the social interest, and relying on local experts. The logic of the case is the logic of one of various alternative ways of reading local consequence, and an array of cases will display an array of possible alternatives. ${ }^{10}$ Such an approach to the role of law in society contrasts sharply with the French tradition of case law, where each case builds on precedent or similar rulings, where punishments and fines are applicable across situations, and where each infraction purportedly has the same punishment regardless of outcome for the wider community.

\footnotetext{
${ }^{9}$ For overviews of the administrative and political foundations of French Native Justice in Morocco, see Henri Bruno, "Cours de Droit Coutumier Berbère" (MS, 1916), in the Bibliothèque Nationale Royale du Maroc, C930; and "La Justice indigène," Cours de perfectionnement des affaires indigènes, Direction des affaires indigènes et du service des renseignements, Résidence Général de France au Maroc (Rabat: Imprimerie du Service des Renseignements, 1924); Jacques Caillé, La Justice Coutumière au Maroc, Extrait du cours, Organisation Judiciaire et Procédures Marocaines, Institut des Hautes-Etudes Marocaines (Casablanca: Imprimeries Réunies, 1945); and Georges Surdon, "Esquisses de droit coutumier berbère marocain," unpublished MS of conferences given in training of the Service des Affaires Indigènes 1927-1928 (Rabat: Institut des Hautes Etudes Marocaines, 1928).

${ }^{10}$ Rosen, "Islamic "Case Law," 317.
} 
We can ask, building on Rosen's argument, what precisely was standardized under the Protectorate: punishments, principles, or both?

European administrators, military officials, and native populations had different conceptions of what constituted law, how it was determined and reproduced, who were its keepers, and what constituted legal authority, and all of these questions were inherent in the standardization of customary law and the functioning of courts. In the Moroccan case, principles and rules were the foundation of the customary laws recognized by the French-supervised makhzan and its spiritual and political head, the sultan. ${ }^{11}$ Berber customary law represented an ideologically informed domain of social action that was elaborated in the formal training of Native Affairs (affaires indigènes) officers, and animated policy debates throughout the Protectorate period. ${ }^{12}$ The political advantage of codifying Berber custom, Izard wrote in 1930, was that it would facilitate eventual transition to something closer to French legislation and thus, he claimed, closer to French values and support for the Protectorate. ${ }^{13}$ Nothing of the kind ever took place, and in an ironic twist, the courts themselves arguably brought Berber communities closer to the Islamic law from which French officials attempted to shield them.

\section{THE BERBER DAHIR AND THE CREATION OF CUSTOMARY COURTS}

On 16 May 1930, a dahir (decree) designed by Protectorate officials was issued by the Moroccan sultan. Often called the "Berber Dahir," it built on an 11 September 1914 decree that stated France's intention to retain customary law among those rural tribes following it rather than Islamic law. What the French did not acknowledge, at least early on, was the central role that custom played in Islamic law throughout the Muslim world, particularly in agricultural and rural affairs, and the significant influence of fiqh on Berber customary law, especially in regards to personal status. ${ }^{14}$ The 1930 decree was written to "regulat[e] the functioning of justice in tribes of Berber custom

11 On the role of the sultan and his vizirs (ministers) under the Protectorate, see also Anthony Clayton France, Soldiers and Africa (London: Brassey's Defence Publishers, 1988), 91-93.

12 For more on Native Affairs officers, see Mustafa El Qadery, "La 'science sociale' des Affaires indigènes au Maroc," in Anthropologie du Maghreb (Fes, 1924); and Roger Gruner, Du Maroc traditionnel au Maroc moderne: le contrôle civil au Maroc, 1912-1956 (Paris: Nouvelles Editions Latines, 1984).

${ }_{13}$ Marc Méraud points out that fifteenth-century France underwent the same process of codifying oral legal tradition. Histoire des A. I., le service des Affaires Indigènes au Maroc (Paris: La Koumia-Public-Réalisations, 1990), 184. While the term "codification" in legal studies necessarily involves writing, Protectorate sources use it as anthropologists do, to mean the uniform application of principles to cases, so that legal "codes" can be oral or textual.

14 Robert Montagne argues that the spread of the makhzan, even in the pro-Protectorate period "ruined" 'urf, as the law once confined to local councils came under the qayds and regional religious scholars who helped apply Islamic law. See his Les berbères et le makhzen dans le sud du Maroc: Essai sur la transformation politique des berbères sédentaires (groupe Chleuh) (Paris: Libraire Felix Alcan, 1930), 389-90. 
not endowed with a mahkama (Islamic court) applying Islamic law." It established customary courts (tribunaux coutumiers) to give legal status to the already existing judiciary councils (djemaâs judiciaires). Both the 1914 and 1930 decrees mandated the urgency of identifying and codifying juridical differences between tribes according to their allegedly Islamic or non-Islamic customary properties. Article 6 of eight in the 1930 decree stipulated that criminal cases in Berber lands be tried under French law, and this became a rallying cry for urban nationalists. Article 6 was rescinded in 1934, and criminal matters for some tribes were put before the qadi (Islamic judge) in the Islamic law courts. ${ }^{15}$ The same year saw the creation of Berber customary appeals courts.

In 1930, urban nationalist opposition to the overall decree took the form of protests and tracts in Rabat, Salé, and Fes, as well as in Paris, Cairo, and Beirut and this marked a turning point in the visibility of a budding anti-imperial movement. Scholars have overlooked the earlier, 1914 dahir, perhaps because it preceded the emergence of a nationalist movement by a decade. Participants in the nascent pan-Arab movement discursively rendered the 1930 dahir into a plot to convert Berbers to Christians, replace Arabic with French, and otherwise foment schisms in the population. ${ }^{16}$ It is often written that French Berber policy was grounded in the concept of "divide and rule," and that the French attempted to limit Islamic law among Berbers in order to Christianize them, even though missionaries did little work there ${ }^{17}$ relative to their sustained and sometimes successful efforts in neighboring Kabylia in northern Algeria. ${ }^{18}$ Some scholarly accounts raise the nationalists who organized the 1930 latif protests to an almost mythical status, and present resistance to the dahir as evidence of an organic national unity against efforts to differentiate between previously undifferentiated ethnolinguistic groups. ${ }^{19}$ Contrary to

${ }^{15}$ My review of Anti-Atlas civil and criminal court registers from the mid-1930s to the mid-1950s period suggests that there was considerable overlap between the types of cases heard by these two courts for a given tribe, particularly in regards to divorce, inheritance, and land transfers. For an overview of the intentions and inadvertent consequences of the dahir, see William Hoisington, "Cities in Revolt: The Berber Dahir (1930) and France's Urban Strategy in Morocco," Journal of Contemporary History 13, 3 (1978): 433-48. As in colonial Uganda and other colonies in the post-World War II period, there was rising consciousness and nationalism, social and economic discontent, and political unrest that all presented challenges to the Protectorate government. See Vincent, "Contours of Change," 165.

16 For an analysis of Middle Eastern and European press coverage of the 1930 dahir, see Gilles Lafuente, La Politique Berbère de la France et le Nationalisme Marocain (Paris: Harmattan, 1999), 213-68.

17 See, for example, P. Ange Koller, Essai sur l'Esprit du Berbère Marocain (Fribourg, Switzerland: Imprimerie St-Paul, 1946).

18 Patricia M. E. Lorcin, Imperial Identities: Stereotyping, Prejudice and Race in Colonial Algeria (London: I. B. Taurus, 1999), 62, and 177-81; and Bertrand Taithe, "Algerian Orphans and Colonial Christianity in Algeria, 1866-1939," French History 20, 3 (2006): 240-59.

19 See Dale Eickelman, Knowledge and Power in Morocco: The Education of a TwentiethCentury Notable (Princeton: Princeton University Press, 1985). Robin Bidwell, notably, remarks that the Berber Dahir evoked no protest in the mountains despite agitation in the cities. See his 
the most commonly circulated narratives about this event, ${ }^{20}$ the urban-based outcry against the "Berber Dahir" neither led to its repeal nor dismantled the courts.

Misleading accounts of Berber justice under the French abound. For example, Spencer's account in his Historical Dictionary of Morocco asserts that the French retaliated against elites creating Arab schools in Fez by issuing the 1930 dahir that "gave equal status to the languages, culture, and customary laws of the Berber tribes," even though the dahir mentions neither language nor culture. Spencer echoes an often-repeated misunderstanding when he claims that, after protests, "The Berber Dahir was rescinded in 1934." 21 In fact the customary courts continued to operate in Native Affairs bureaus in civil and military zones up until 1955 or 1956; just how long they carried on varied with the pressures that nationalist activity placed on the judicial council members to cease their involvement with them, and eventually, in some cases, to close them down.

For twenty-five years, these courts registered marriages, births, divorces, and deaths. They heard and resolved disputes over land use and ownership. They divided estates by drawing up and evaluating existing genealogies, establishing land inventories and plot boundaries, and calculating the amount and type of land to be distributed to different parties. They recorded land and property transfers according to written or unwritten customs in place prior to the tribes' submission to the makhzan and the French. The courts thus acted as both notaries and sites of arbitration for rural Moroccans. The majority of civil disputes heard in Anti-Atlas mountain courts in southwestern Morocco

Morocco under Colonial Rule: French Administration of Tribal Areas 1912-1956 (London: Frank Cass, 1973).

${ }^{20}$ See for instance Allal Al-Fasi, Harakat al-istiqlaliyah fi al-maghrib al-arabi (Cairo: Al Risala, 1948); Jacques Berque, French North Africa: The Maghrib Between Two World Wars (New York: Frederick A. Praeger, 1967); Kenneth Brown, "The Impact of the Dahir Berbère in Salé," in E. Gellner and C. Micaud, eds., Arabs and Berbers (Lexington: Lexington Books, 1972), 198-202; M. E. Combs-Schilling, Sacred Performances: Islam, Sexuality, and Sacrifice (New York: Columbia University Press, 1989), 280-83; John P. Halstead, Rebirth of a Nation: The Origins and Rise of Moroccan Nationalism, 1912-1944 (Cambridge: Harvard University Press, 1967); David Hart, Tribe and Society in Rural Morocco (London: Frank Cass, 2000), 1617; William Hoisington, "Cities in Revolt"; Abdallah Laroui, Les origines sociales et culturelles du nationalisme marocain (Paris: Maspéro, 1977); and Lawrence Rosen, Bargaining for Reality: The Construction of Social Relations in a Muslim Community (Chicago: University of Chicago Press, 1984), 63.

21 William Spencer, Historical Dictionary of Morocco (Metuchen, N.J.: Scarecrow Press, 1980). Even the esteemed Berberist David Hart is prone to exaggeration in Tribe and Society in Rural Morocco, 16-17. But see alternative accounts: Mustafa El Qadery, Politique berbère et lecture du XX siècle marocain (IRCAM: Rabat, 2004); and "La 'science sociale"; William Hoisington, The Casablanca Connection: French Colonial Policy, 1936-1943 (Chapel Hill: University of North Carolina Press, 1984), 29-39; Lafuente, La Politique Berbère de la France; and Mohamed Mounib, Adhahir 'al barbari' akbar ukduba siyassiya fi l-maghrib al mu'aâssir (Rabat: Dar Bou Regreg, 2002). 
involved either land use rights, with plaintiffs accusing adversaries of unduly occupying and harvesting small plots of barley or almonds, or requests by relatives and spouses for the division of estates. Interspersed with these disputes were changes in personal statute, especially regarding marriage and divorce, but also adoption and guardianship. ${ }^{22}$

In light of the pivotal symbolic importance of opposition to the Berber customary courts in narratives of Moroccan nationhood, surprisingly little has been said or written about the courts themselves: how they functioned, who staffed them, and how they shaped French native policy and weighed on French empire more generally. Yet, as I will argue here, the courts themselves - and not just the political polemics around their creation-were crucial sites for the negotiation of relations between Moroccan subjects and French administrators, and for attempts to implement French ideas about ethnicity, human progress, and civilization. In important respects, these courts were the Achilles' heel of French empire. But whatever ideological or political purpose they succeeded or failed in attaining, the courts were crucial to the administration of the everyday lives and lifecycles of rural Berbers. To allow tribes to "retain" their customary law was not an altruistic decision. Instead, as Read has argued for sub-Saharan Africa, it signaled an acknowledgment that customary law was "increasingly more convenient as administrative authority developed; in particular the imprecision and adaptability of rules of customary law made them useful instruments for preserving administrative control and buttressing recognized African authorities. ${ }^{23}$ Comparing systems of native law under French rule, Scham observes that Moroccans "were allowed to maintain and reform their traditional courts, whereas in Algeria the natives were judged by French courts in all criminal cases." ${ }^{24}$ Yet arguably, pre-Protectorate judicial practices in Morocco - a repertoire of legal means featuring arbitration that shifted with circumstances, as customary law tends to do - devolved into a parody of French-appointed proxy juries. The customary courts acknowledged non-Islamic features of Berber social organization, which although widely practiced had previously been transmitted in oral or written form but not officially acknowledged outside the tribe itself. It was the textual encoding of legal customs, in French, that most upset and embarrassed some Berbers who considered themselves good Muslims. Official recognition of local custom led

${ }^{22}$ My remarks here are based on reading over twenty thousand court cases (in both the ad-hoc registres brouillards and the registres de jugements) recorded in the four customary courts (tribunaux coutumiers) based in Igherm (each with jurisdiction over one to four tribes), and the court of Ait Abdallah (later called Illalen de l'Est) between 1936 and 1956. These court dockets are unclassified and stored at the Markaz qadi al muqim, Igherm.

${ }^{23}$ J. S. Read and H. F. Morris, Indirect Rule and the Search for Justice (Oxford: Clarendon Press, 1972), 168

${ }^{24}$ Alan Scham, Lyautey in Morocco: Protectorate Administration, 1912-1925 (Berkeley: University of California Press, 1970), 200. 
some rural elites to request of the sultan and French authorities that they be assigned a qadi (Islamic judge) rather than a judiciary council. ${ }^{25}$ In this respect, one consequence of the 1930 dahir may have been the further spread of Islamic law in rural areas. The widespread contention that the French removed Berber areas from Islamic law is empirically untenable in several respects. Among many Berber tribes, including most of those in the Sous and Anti-Atlas mountains of southwestern Morocco, Islamic law was already in place for several key areas of personal statute even in the absence of a qadi, whereas customary law was used for civil and penal matters, for which the tribe or tribal faction required a consensus of male heads of households, with the results publicly displayed at markets. ${ }^{26}$

\section{PROTECTORATES AND COLONIES}

Before discussing in more detail the functioning of the Berber customary courts under the French Protectorate, a word about the legal and political status of protectorates and colonies is in order. Officially, colonial rule was direct while protectorate administration was indirect. In reality, there was significant slippage between the two. ${ }^{27}$ In the protectorates, the French worked with local officials but kept the political power largely within the institutions they found at submission. Under the French Protectorate of Morocco, some areas of administrative, economic, political, and legal life were left in the hands of the sultan and his makhzan, particularly in the urban areas and especially north of Marrakesh. In the southern half of the country, around the administrative centers of Marrakesh, Taroudant, Ouarzazat, and Tiznit, rule was consolidated in the hands of the so-called "grand qayds," whose regional authority the French backed so long as they tacitly supported Protectorate policies and goals. ${ }^{28}$ The lower-level qayds and khalifas carried out much of the Protectorate's logistical and administrative work in the Moroccan countryside: tax collection (the tertib); the organization of corvée mandatory male labor for the building of roads, buildings, and other infrastructure; and, at least until 1934, the rallying of troops from submitted tribes as they accepted "the French peace of the Sharifian

25 See, for instance, the request made on behalf of the Ida ou Zeddout people in 1935, in K. E. Hoffman, "Purity and Contamination: Language Ideologies in French Colonial Native Policy in Morocco," Comparative Studies in Society and History 50, 3 (2008): 734-35.

${ }^{26} \mathrm{I}$ am indebted to Mohamed Mounib for this detail on the consensus of penal fines. For more on the specific areas of customary law codified in extant documents, see the contributions in Organisation Tamaynut, ed., Le Droit Coutumier et les législations au Maroc (Rabat: Organisation Tamaynut, 2007). For punishments stipulated in extant documents in Berber customary penal codes, see David Hart, "The Penal Code in the Customary Law of the Swasa of the Moroccan Western Atlas and Anti-Atlas," Journal of North African Studies 3, 4 (1998): 55-67; and Louis-Joseph-AdolpheCharles Hanoteau and Aristide-Horace Letourneux, La Kabylie et les coutumes kabyles, vol. III (Paris: Challamel, 1893).

27 Hoisington, The Casablanca Connection, 104.

28 William Hoisington, Lyautey and the French Conquest of Morocco (New York: St. Martin's Press, 1995), 93-108; El Qadery, "Politique berbère," 5. 
Empire" (la paix francaise de l'empire chérifien), for the so-called "pacification" of remaining dissident tribes. ${ }^{29}$ All of these activities resulted from directives from the French Residence General in Rabat, the military commanders of each military region (including Marrakesh and Agadir), and from the Native Affairs officers who ran each rural outpost. The latter often served alone or with a single assistant who could be French, Algerian, or Moroccan.

Native policy (la politique indigène) at the outset was premised on Resident General Lyautey's fundamental principle that existing structures should be preserved, and Moroccans administered but not ruled. ${ }^{30}$ At all costs, the Protectorate was to avoid the problems of Algeria, and simply improve on the institutions they found in place to the extent that they facilitated French administration. In the early twentieth century, the Moroccan sultan was recognized as a spiritual authority by much of the population, but this did not translate into political allegiance or willing tax remuneration. Morocco was simply in France's trusteeship, or under its tutelage, until its sultan and its central government could consolidate their control over the whole of Morocco's territory.

For European powers, native courts were a key mechanism of indirect rule, as Morris has argued for East Africa, for they were the sites where the mainly unwritten customary law was sanctioned by authorities, which both pleased local populations and furthered rulers' political agendas. ${ }^{31}$ Local powers in charge of indirect rule bolstered their authority by invoking "traditions," legal or otherwise, to maintain public order, to the benefit of certain social groups over others. ${ }^{32}$ While the French retained the title and veneer of

29 El Qadery, "Politique berbère," 10. Similarly in Uganda, in transforming agrarian society and building infrastructure, the British colonial state looked to an African indigenous law that required every able-bodied man to work unpaid on public works projects for a month each year. See Vincent, "Contours of Change," 161. The French evoked the Berber twiza collective laboring practice for French corvée labor. See Robert Aspinion, Contribution à l'étude du droit coutumier berbère Marocain (Etude sur les coutumes des tribus zayanes) (Casablanca: Editions A. Moynier, 1937), 57-58, for the Middle Atlas Zayan tribe; K. E. Hoffman, We Share Walls: Language, Land and Gender in Berber Morocco (Malden: Blackwell Publishers, 2008), 97-98, for the Sous; Hanoteau and Letourneux, La Kabylie et les coutumes kabyles, vol. II, 60, for Kabylia; and Robert Montagne, Les berbères et le makhzen dans le sud du Maroc, 247-48, for a comparison of regions. Similarly, British officials in Uganda retained Luganda terms that "hid the degree to which these were colonial innovations." Vincent, "Contours of Change," 161.

${ }^{30}$ See selected letters collected in Louis-Hubert Lyautey, Paroles d'action, George Duby, ed. (Paris: Editions de la Porte, 1995); Bidwell, Morocco under Colonial Rule; Hoisington, The Casablanca Connection; and Lyautey and the French Conquest of Morocco; Gilles Lafuente, La Politique berbere; Douglas Porch, The Conquest of Morocco (New York: Alfred A. Knopf, 1982); Alan Scham, Lyautey in Morocco: Protectorate Administration, 1912-1925 (Berkeley: University of California Press, 1970); and Georges Spillman, Du Protectorat a l'Indépendance: Maroc, 19121955 (Paris: Plon, 1967), 196-97.

31 H. F. Morris, "Native Courts: A Cornerstone of Indirect Rule," in J. S. Read and H. F. Morris, eds., Indirect Rule and the Search for Justice (Oxford: Clarendon Press, 1972), n.p.

32 See Eric Hobsbawm, "Introduction: Inventing Traditions," in Eric Hobsbawm and Terrence Ranger, eds., The Invention of Tradition (Cambridge: Cambridge University Press, 1983), 1-14; Martha Kaplan, "Luve Ni Wai as the British Saw It: Constructions of Custom and Disorder in 
Berber customary law, they gradually transformed the administration of justice and its personnel such that their oversight was quasi-complete; council members were hand-selected or approved by French officials, and all rulings had to be endorsed by the governing authority. Court dockets and written accounts of oral court proceedings for important cases (procès verbaux) were at the center of bureaucratic practices that were alien to pre-Protectorate Berber justice.

\section{LAW IN THE MORAL PROJECT OF COLONIAL ADMINISTRATION}

French Protectorate authorities and colonial legal scholars were attentive to law as a window into "Berber psychology." 33 They took legal principles, even more than verbal or non-verbal cultural practices, to be the heart of Berber identity. Native Affairs and military officers assessed tribal legal codes and compiled tribal reports (fiches de tribus) in response to Resident General Lyautey's (1912-1925) early ethnological forays into what he called simply la société berbère. $^{34}$ Underlying the spirit of Lyautey's query was a sense that the various articulations of Berber customary law were inherently distinct from, and even hostile to, the Islamic shari' $a$ law more closely identified with Arab populations, the makhzan, and the sultan. Early tribal reports were largely concerned with geography and ethnographic topics, including tribal laws, customs, economies, political structures, and key individuals (especially allies and enemies) and their territories of influence. After pacification, Native Affairs officers went further and compiled lists of male conscripts to build roads leading toward still-dissident tribes, conducted censuses of landholdings and harvests for levying taxes on pacified tribesmen, and standardized registers for births, marriages, divorces, deaths, land transfers, and dispute arbitration. Tribal reports became increasingly economic and political in content, recording work projects and economic development problems in relation to forestry, mining, and other sectors.

The French effort to ordain some tribes as customary law-abiding and others as Islamic law-abiding was troubled by the finding that many tribes seemed to follow mixed legal systems. ${ }^{35}$ Moreover, given that both the 1914 and the 1930

Colonial Fiji," Ethnohistory 36 (1989): 349-71; John D. Kelly, "Fear of Culture: British Regulation of Indian Marriage in Post-Indenture Fiji," Ethnohistory 36, 4 (1989): 372-91.

33 Georges Surdon, "Esquisses de droit coutumier berbère marocain."

34 See Comité d'études berbères de Rabat 1915/1916, discussed in Hoffman, "Purity and Contamination," 731-33.

35 Montagne compares legal Islamization to linguistic Arabization in terms of overlap, borrowing, and multiple stages of transition, noting, "all the tribal groupings that interest us are found in this indistinct state." While acknowledging that drawing a clear distinction between Islamic and customary law-abiding tribes was difficult, he urged, "Let us try nonetheless to specify the nuances." Robert Montagne, "Le régime juridique des tribus du sud marocain," Hespéris 3 (1924): 326. 
dahirs explicitly provided for the maintenance of tribes' juridical traditions, it is surprising that many allegedly customary law-abiding tribes in regions such as the Sous were not officially registered as such. Indeed, even prior to the 1930 dahir, judiciary councils operated, according to the tribal reports, to administer the mixed shari 'a and 'urf (customary law) practices of the Ida ou Zeddout, Indouzal, and Ida ou Knsous tribes. The customary courts held in Igherm, in the eastern Anti-Atlas mountains, were shared by a dozen tribes, several of whom were not officially recognized as customary law-abiding. Likewise in the Sous plains, for instance in the Arghen tribe, the French did not officially recognize customary law. The Qayd Tiouti, in the Taroudant region, "d[id] not hide his hostility with regard to 'urf, no more than [did] the merchants of the annex living in the Gharb." 36 The same was true of tribes under the Qayd Glawi who, although majority Berber and customary law-governed, were never classified as such. Instead, a Berber living outside Glawi's lands was classified as "musulman non juridique," whereas a Berber living within them was a "musulman juridique. ${ }^{37}$ Just as customary juridical practices were "bastardized," as Morel Francoz claimed, ${ }^{38}$ so too were the means that administrators established to adjudicate complaints and arbitrate conflicts. General Protectorate policy was to encourage Berber customary law where it existed, yet this was challenged as officials learned that in many cases Islamic law seemed better suited to French values and interests. This was particularly true with personal statute law around marriage and inheritance. The legal scholar George Surdon, who taught courses on Islamic and customary law to Native Affairs officers in training at the Institut des Hautes Etudes Marocaines in Rabat, and had served in other French colonies and protectorates, identified inheritance as a central preoccupation for Berbers. He lectured, "You are today the first to have this lesson. Consult the mirror of customary law. The three poles of Berber life appear plain and clear: land and herds. Women. Pacts of solidarity. The Berber, as you know, has only one preoccupation: assuring by all means possible the integrity of his inheritance." 39 of course, land and herds were also central concerns of the European settler colonists (colons) as they pursued commercial agricultural ventures. Colons had already been purchasing dissident land, outside of the purview of extant French-endorsed laws, and often at scandalously low prices. Protectorate officials saw the potential danger of allowing this to continue.

\footnotetext{
36 Letter of 20 Nov. 1946 from Capt. Perrony to the Chef de Cercle in Taroudant, in Service Historique de l'Armée de Terre, Vincennes (SHAT), Série 3H (Maroc 1877-1960), 2073.

37 El Qadery, "Politique berbère," 12.

38 See Robert Morel-Francoz, "Organisation judiciaire des tribus berbères de l'Anti-Atlas" (Paris: CHEAM, ca. 1939); and J. Lafond, "Les sources du droit coutumier dans le Sous: le statut personnel et successoral," unpublished report, 1947, in SHAT 3H 2017.

39 Georges Surdon, "Esquisses de droit coutumier berbère marocain," 15.
} 
In addition to French economic concerns, the issue of legal pluralism raised ideological dilemmas. Certain customs were clearly contrary to French concepts of justice, particularly those concerning women and inheritance. These provoked much hand-wringing among Protectorate authorities, but little in the way of reform. Other customs potentially threatened political stability, such as the customary law (similar to Islamic law) among some tribes that allowed women to divorce absent husbands. This was a popular practice among the spouses of emigrants, and the French feared it might lead to a "women's revolution" that would exacerbate men's resistance to Protectorate administration. Administrators of other French territories had similar concerns. Protectorate officials consulted case studies to help them resolve their policy dilemmas, one example being a 1910 report by the legal scholar Marcel Morand called "Etudes de Droit Musulman Algérien" (Studies of Algerian Muslim law), which became staff reading at one of the Atlas mountain posts and made its way into the archives of the Protectorate's Service des Renseignements. Morand, then Dean of Law in Algiers, wrote about the quandary of discovering that non-Arabized Berbers considered marriage a "sale." "I0 In a section entitled "l'Islamisation des Populations de l'Aurès" (The Islamization of the Aures population), Morand asked rhetorically whether this was a practice worth preserving or whether it was instead an area in which Islamization might be "to our advantage." He continued, "On the one hand, Islamic law is more humanitarian than [Berber] customary law, especially for women. But while it may bring about civilization, it also closes off the possibility of assimilation and progress." 41

We see here the widespread French fear that encouraging Islamic law for selected practices, like inheritance, would have the infelicitous effect of encouraging the more generalized religious Islamization-and linguistic Arabization - of Berber communities. This was not a mere philosophical rumination; resolution was necessary for the smooth functioning of Berber justice by French means. A still larger issue plagued colonial regimes in many locales, that of the purported utility of law as "an ideological cornerstone of the civilizing process." 42 Of particular interest in the Moroccan case was how violations were punished. In Berber law, punishment could take the

\footnotetext{
40 This popular idea was incorporated into Native Affairs officer training; see Bruno, "Cours de Droit Coutumier Berbère," lesson 7.

41 Marcel Morand, Etudes de droit musulman algérien (Algiers: Jourdan, 1910, and Centre des Archives Diplomatiques, Ministère des Affaires Etrangères, Nantes (CADN), Protectorat du Maroc, 1912-1956, DAI 31). See also Lorcin, Imperial Identities, 67, regarding the French view of women's status as an indicator of broader social traits. On French attempts to change customary law so as to change women's roles in Algeria, see Alain Mahé, Histoire de la Grande Kabylie, $x i x^{e}-x x^{e}$ siècles. Anthropologie du lien social dans les communautés villageoises (Paris: Éditions Bouchêne, 2001).

42 Sally Engle Merry, Colonizing Hawai $i:$ The Cultural Power of Law (Princeton: Princeton University Press, 2000), 8.
} 
form of monetary or material compensation to the tribe, but not imprisonment. Extreme violations brought banishment from the tribe, exposing the offender to possible death. ${ }^{43}$ If fines were inflicted instead of imprisonment, how would these be enforced on subjects who had nothing to hand over? This led to widespread abuse in Algeria, Tunisia, and Morocco, where impoverished natives could be deprived of even their last goat, and a blanket was considered a luxury and similarly subject to seizure. There seems to have been variation in the application of harsh fines, for eventually a list of inalienable goods was formulated and circulated, with the explanation that a Moroccan subject could not be stripped of basic household necessities. ${ }^{44}$ In the Anti-Atlas, under the Protectorate, imprisonment was more common than fines, for both men and women. Offences that brought imprisonment included not only theft, battery, and the rare rape or murder, but also violations created by the colonial encounter and Protectorate administration: insolence towards Protectorate authorities and French-appointed local authorities such as the amghar (Arabic shaykh) or judicial council members, and non-compliance with rotating forced-labor projects that included road building, hauling wood and lime, delivering mail, and running errands for the French authorities.

\section{ORDER IN THE COURT}

In the Islamic world, as in many other places, the world of formal courts offers a stageas intense as ritual, as demonstrative as war-through which a society reveals itself to its own people as much as to the outside world. ${ }^{45}$

Multiple levels of interpretation and vast networks of paperwork had to be generated in order to make official the doings of things allegedly as they always had been done. All of this paperwork around the customary courts required manual and intellectual laborers, ranging from the largely unskilled but often loyal and reliable couriers to the highly skilled polyglot translators, interpreters, clerks, and assistants without whom communication and mediation between Berber, Arabic, and French was impossible. ${ }^{46}$

${ }^{43}$ See for example the letter written just before the application of 16 May 1930 dahir by the Director General of the Native Affairs' Military Cabinet to the Procureur Général of appeals, in CADN Maroc DI 732.

44 See the Journal officiel of June 1933, quoted in an undated report by the Masonic lodge Le Grand Orient de France, entitled "Le Malaise Nord-Africain-les remèdes," for the Guernut Commission, in Centre des Affaires d'Outre-Mer, Aix en Provence (CAOM) FM Guernut 43. The masons asserted that the only way to avoid rural poverty was to ensure that each family had an inalienable parcel of 10 to 15 hectares of land.

45 Rosen, "Islamic 'Case Law," 318.

46 Bernard Cohn writes that the colonial British in Bengal similarly did not know the local language. For this reason, the Bengali spoken by litigants had to be translated into Persian and then English, with the end result being a heavy reliance on locals whom the British, like the French, suspected as being unreliable. Bernard Cohn, "The Command of Language and the Language of Command," Subaltern Studies 4 (1985): 296. 
Native Affairs officers in the Moroccan countryside oversaw the weekly or biweekly operation of the customary courts. On this we have testimony from Marcel Turnier, who served as a Native Affairs assistant in the Igherm post of Taroudant Province from 1932-1934, and then returned for a two-year stint as bureau chief in June 1939. His is one of only a few descriptions we have of the stage on which Berber customary court sessions were set. Turnier writes that his two years as bureau chief passed quickly and were full of the tasks arising from pacification, since much of his region had resisted the Protectorate until 1934. He called these tasks "law, taxation, territorial development." He says his legal supervisory duties were "absorbing," and his account hints at the layers of linguistic interpretation required by the court proceedings:

My assistant and I divided this tedious chore [besogne fastidieuse]. Every two weeks, it was my turn. Beginning Monday morning, I barely finished my chicaya [complaints session $]^{47}$ by Thursday evening. The Shluh of the region were hardcore quibblers [chicaneurs en diables] and we would often see an old woman who had walked 40 kilometers to complain of a stolen egg. Under my supervision, justice was rendered by a council composed of the country's notables. The interpreter translated into Arabic for me the parties' complaints expressed in the Shluh dialect, which I still speak imperfectly. Long and exhausting work. Sometimes I got irritated and threw my files at the heads of parties acting in bad faith - the assembly members then smiled seemingly indulgently and with understanding - but if my reactions were violent and rare, our law was, I think, fair. Our court was never empty. ${ }^{48}$

Another description of the courts comes from Georges Surdon, who in an undated report, probably from the 1930s, described what he called "a judicial assembly session in the land of Berber custom". Here is how he portrayed the courtroom and its personnel:

The scene is nothing if not picturesque. A large room with bare walls. On the ground, a few mats. The assembly members, five to ten local notables, with the rough gray beards of warrior peasants, are seated on the mats, not in the Arab style with crossed legs, but on their heels, their knees up to their chins. Next to them is a white wooden table where two people are crouched [accoudés]: one is the clerk-secretary responsible for recording the arguments; the other is the Native Affairs officer or the civil comptroller/inspector [controleur civil] responsible for ensuring that all takes place in an orderly fashion.

Once called, the parties squat on either side of the assembly and challenge each other with a steady gaze (se défient du regard). Initially all goes according to plan in a relative

\footnotetext{
${ }^{47}$ In this article, italicized Arabic or Berber words followed by an English gloss in brackets indicates usage of the Arabic or Berber in the original document. I have retained such words to give a sense of French officials' usage of Moroccan terms they considered commonplace enough to pass without translation. Otherwise, an English gloss followed by the French original word or phrase in brackets (such as in the following sentence here) is used to offer readers of French a sense of these documents' sometimes colorful phrasing. When the original text contained an Arabic/Berber word or phrase followed by a French gloss in parentheses, I have retained this usage, as in the example later in this passage.

${ }^{48}$ In Marc Méraud, Histoire des A. I., le service des Affaires Indigènes au Maroc (Paris: La Koumia-Public-Réalisations, 1990), 339.
} 
calm. But almost as soon, the adversaries begin to clamor [vociferer], each believing that the louder he yells the more true his cause will seem. If they belong to two different clans, two opinions soon become the focus of the assembly and soon everyone cries out for the inspector to intervene. He summarizes the complaint, collects the majority opinion and has them come to a decision [fait prendre la decision]. The adversaries leave, throwing each other dirty looks full of fury but satisfied that the proceedings have broken up. Another case is called and the session continues. ${ }^{49}$

The description then continues with a note as to the ease with which Berbers could take their complaints to the customary courts, since in many regions minimal or no fees were required to enter complaints into the registers, due to an explicitly political decision made by Protectorate officials to bring rural populations closer to the institutions of the French-administered makhzan:

This expeditious justice is inexpensive, even free in many corners of the mountains; it assures respect for customary law to which Berbers are above all attached; and it pleases them very much and helps reconcile them with the makhzan and with France since, up to the present day, what they lacked most was justice. For it is to justice that these rustic, aggressive, and quarrelsome people are most sensitive [Or, c'est à la justice que ces êtres frustes, batailleurs et processifs sont le plus sensibles].

Notice that in Surdon's unapologetically paternalistic description there is no mention of a court clerk. There are no interpreters to render the assembly's decision to the scribe. The process of recording the verbal exchange is invisible, and translation between languages is left unexamined. And what was the alleged role of the Native Affairs officers? The best they probably could do, this and other documents suggest, was to ensure order in the courtroom, and some did so by either overtly or covertly encouraging litigants to believe that they, rather than the judicial council, were in charge of the court proceedings. This complexity, ambiguity, and insufficiency were not supposed to be part of the Protectorate legal system. Language was anything but transparent, and the ways in which pre-Protectorate indigenous law was transformed into colonial-endorsed customary law remained obscured from participants.

Surdon's account suggests a tidy dispute that leads to a ruling by the end of the initial presentation of facts. Yet a good proportion of cases brought to court required more steps and court appearances prior to resolution. Genealogies and deeds were often difficult for parties to locate or procure, especially if they were in the hands of a reluctant gatekeeper or a room in a collective storage facility (agadir) to which the key was lost or in jealous hands. When parties did present deeds, inscribed on either wooden planks or scrolls of paper rolled into bamboo tubes, they often did not pertain to the case at hand, a fact that non-literate parties could not verify without recourse to a fqih. There was often an onsite investigation carried out by two or three judicial council members or by one member and the local fqih to verify use rights, ownership, and family ties.

\footnotetext{
49 Georges Surdon, "Une séance de Djemaa judiciare en pays de coutume berbère," unpublished report, n.d., in CAOM ala/gga/31h/2 (n.d.).
} 
This committee reported back to the court on the parties' truth claims. When one or the other party in a case was sentenced to swear an oath, either alone or with a designated number of co-jurors - "a very serious act" cally in the presence of a judicial council member and at the site of a local saint's tomb or village mosque. The summaries of proceedings in the registres brouillards suggest that judicial assembly members had an active and wideranging set of responsibilities outside of the court hearings themselves.

Judicial assemblies were constituted so as not to upset local sensibilities. In the Middle Atlas this meant that most members were unschooled but highly knowledgeable tribal notables, ${ }^{51}$ whereas in the Sous the assemblies consisted either partially or entirely of literate religious scholars (tulab, sing. talib; or fuqaha, sing. fqih). According to a Guernut Commission report, "These customary jurisdictions are comprised of Berber notables, known in their tribes for their knowledge of local custom. Their number, usually a function of the ethnic division of the group, varies from five to ten titular members and three to five additional members, also appointed by ministerial decree. This judicial organization thus retains the representative system that is dear to Berbers, and ensures that it will be upheld according to their particular usage in specific [tribal] fractions." 52

Some regions included fuqaha in equal numbers to tribal notables. In any of these configurations the assemblies were a French invention, given that prior to French occupation the male adult members of the tribe decided on principles and fines by consensus approved by the local assembly, whose membership rotated to assure equal representation of different clans' interests. When the parties disagreed on a ruling, they took their case to an arbiter, and if necessary then a second one. If the parties were still dissatisfied with the arbiters' rulings and went to a third one, the latter's ruling became definitive and was enforced by the council. In the pre-Protectorate period, personal status matters were handled by the local fqih without recourse to a council.

In addition to the judiciary court members, the personnel who staffed and oversaw the Protectorate's customary courts were key to its smooth operation.

${ }^{50}$ N.A., "Une enquête ethnographique et sociologue allemande sur l'Afrique du nord. Transl. Maurice de Prandieres and Robert Montagne," Unpub. MS (1924), 44.

51 El Qadery, "Politique berbère," 10.

52 Commission Guernut, "Organisation \& fonctionnement de la justice indigène au Maroc," CAOM FM Guernut 37, 13. The short-lived Guernut Commission was established under the left-wing Popular Front of Blum's government in 1937 to assess the "legitimate complaints and aspirations of the natives" in French colonies, territories, and protectorates so as to recommend improvements in their standard of living. Reports claimed that the organization and function of native justice left much to be desired. The beginning of World War II, and the rise of the Vichy regime, ended the Commission, but it yielded fruitful studies and critique nonetheless. This unsigned, May 1938 report was forwarded in triplicate by Resident Général Noguès to the Commission's director Henri Guernut (1876-1943), a former president of the Ligue des Droits de l'Homme. It was presumably compiled and authored by a mason named R. Bérenger, since he was tasked with justice and legal codification. On the committee's composition, see CAOM FM Guernut 21. 
These included the Native Affairs officer of the annex where the sessions were held (locally called the hakim) and the clerk (greffier). Native Algerians, Tunisians, and Arabophone Moroccans often served as secretaries or scribes, their titles and compensation dependent on their training and education. The most talented (though not necessary most educated) produced easily readable, comprehensive accounts of court cases that sometimes went so far as to directly quote the parties, translated into French with some Tashelhit terms. These registers provide valuable insight into the language of the court proceedings.

Two divisions of the Protectorate administration had long been trying to develop a project to regulate and codify the clerks' status to reflect what the Kabylia-born French Captain Saïd Guennoun called "the linguistic and legal knowledge demanded of them, their delicate and demanding work and their real responsibilities. Currently, given their status as assistants [auxiliaries], they are not granted the advantages given to civil servants, and their salary is inadequate. Moreover, their professional requirements are becoming more and more specialized." ${ }^{, 3}$ The clerks were "truly the linchpins [chevilles ouvrières] of the customary courts," he wrote, and thus deserved an official status worthy of their efforts. ${ }^{54}$ Little came of this or many other proposed reform measures, like direct recruiting from the Collège Berbère in Azrou, an institution intended to give young Berber men a French education in preparation for civil service employment but which instead became a cauldron of Araboislamic nationalist activity. ${ }^{55}$

\section{Interpretation in the Courts}

Court proceedings were multilingual communicative events from beginning to end. ${ }^{56}$ Caillé explains that cases were introduced either in written French and filed with the clerk, or in spoken Tashelhit with a clerk who filed a written summary in French. The plaintiff specified the subjects of the request and the names, characteristics, and residences of the parties. These requests were recorded in a docket in the order received, and dated, accompanied by a court fee if applicable or a certificate of indigence. The clerk then called in the parties. Interestingly, Caillé notes that the nature of the case was not communicated to the defendant: "He is only convoked on a certain day and time before the tribunal coutumier; since recourse to the courts is always preceded

\footnotetext{
53 Saïd Guennoun, "Notes personnelles succinctes sur le commandement et la justice indigène au Maroc," unpublished report, 193 in CADN Maroc DAI 444.

54 See also Mustafa El Qadery, "Saïd Guennoun ou Tiherci d'un intellectual 'indigène,"” Awal 30 (2004): 71-87, for a biography of this fascinating officer. This idea of the "linchpin" reappears in Caillé, La Justice Coutumière au Maroc, 6.

55 Mohamed Benhlal, Le collège d'Azrou (Paris: Editions Karthala et Ireman, 2005), 333-53.

56 Methodological and technological constraints greatly limit our ability for historical analysis of language used in Protectorate courts. For what can be known by the framing of arguments in court records, see John M. Conley and William O'Barr, Just Words: Law, Language, and Power (Chicago: University of Chicago Press, 1998), 116-28.
} 
by discussions en tribu, the defendant will be familiar with the reasons he is being called in." Convocation was done through a bulletin in French and Arabic, taken out of a notebook (carnet à souche) and delivered by an agent de controle and the qayds who alerted the mokhzanis working for the court, who then alerted the parties. Caillé writes, "The law does not set the deadlines between delivery and convocation and the date of the hearing, but it is usually long enough to allow the defendant to get to the place where the court is held." My review of correspondence from the five Igherm-area courts from 19301956 indicates otherwise, for parties working in the North (not to mention in France or Algeria) repeatedly failed to appear in court; a telegram or letter from the Captain sometimes arrived a day or two before the scheduled court appearance on the other side of the country. Impassioned pleas from migrants sometimes pushed the limits of the party's familiarity with written French or, in many cases, indicated recourse to a professional scribe, or perhaps French-schooled family member or friend, with the party signing their name in Arabic or French or with an inked thumb.

"At the hearing" itself, Caillé records, "the court members sit next to the commissaire [government representative] who helps the clerk and the debates take place in Berber and Arabic. The clerk calls out the case. The parties come forward and the rays (tribal leaders) or in some tribes specially trained members of the court question them. They supply their explanations and the commissaire gives his opinion, usually only in oral conclusions." Writing about the Sous, Lafond notes that the plaintiff often presented his prepared complaint in Arabic, but that the defense, "always on another level of emotion," tended to be in Berber. ${ }^{58}$ Debates in court were oral, and although Caillé claims that written accounts were rare I found that some clerks did in essence produce them in their summaries. ${ }^{59}$ More elaborate written accounts were sometimes available for cases that went to appeals. In principle, the parties appeared in person, but they might instead assign proxies (mandataires) if they managed to inscribe this status with the courts in time. Rural residents traveled up to 40 kilometers to reach court in Igherm, presumably by foot or donkey, and the trip would take several days if they lived in Casablanca or Marrakesh. Missing one's case could have serious repercussions; a non-appearing defendant summoned twice within eight days merited a default decision, and the defaulter could be sent to prison. Just as commonly in Igherm, however, the case was simply dismissed.

57 Caillé, La Justice Coutumière au Maroc, 16-17.

58 J. Lafond, "Les sources du droit coutumier dans le Sous: le statut personnel et successoral," unpublished report, in SHAT 3H 2017 1948, and in Jacques Berque, "Le Droit du Sous," Opéra Minora, vol. I (Paris: Éditions Bouchène, 2001), 448.

59 Caillé, La Justice Coutumière au Maroc, 16-17. 
Contemporary accounts rarely mention language use as Caillé, Lafont, and Turnier do, but we can infer from their writings that the local Berber vernacular was indeed spoken in court. ${ }^{60}$ Tashelhit seems to have been the main language for eastern Anti-Atlas court proceedings, judging from the liberal sprinkling of Tashelhit terms in court dockets, but since we have no transcripts or recordings we cannot know for certain. We do know that most parties were monolingual Berber speakers. Some of the men would have been bilingual with vernacular Arabic from their contacts through work and markets with Arabic speakers, and some may have had some familiarity with written and recited classical Arabic from childhood training in a msid (Qur'anic school). We know that very few women knew any Arabic. Overall then, we can safely assume that most plaintiffs presented their cases in Berber to a Berber-speaking judiciary council whose members may or may not have known some colloquial or classical Arabic.

Interactions between plaintiffs and councils were mediated by the French Native Affairs or military officer (the hakim) and by his right-hand man, who may have been a local adul (notary) or fqih or alternatively just an elderly respected man (afqir) informally selected to help with translation, assistance, and general guidance. During each case, the officer listened to the plaintiff and defendant in turn, asking the fqih / adul / fqir for his opinion on the validity of the claims. Officers were better positioned to assess a case's validity if they had spent years in their rural posts, spoke Berber, and knew family genealogies and alliances. While the judiciary councils ostensibly heard cases and decided on rulings, this was done under the supervision of the French governmental representative, who tended to weigh in on case outcomes according to the advice he received from these local men. This procedure was neither officially recognized nor described in contemporary accounts, but I heard about it in three separate interviews: from ninety-five-year-old Da Hammou from Ait Abdallah, who drew on personal experience; from fifty-five-year-old adul Mohamed Guercif in Igherm, whose father (Abdallah ben Belqasm aka 'Tagmouti') served as adul for Captain Ropars in the 1950s; and from Ali Achfur, secretary of the Igherm court and nearing sixty years of age. These interviews substantiate the critique launched by one French observer who wrote, "We should say it is the captain's court, not the Ayt [Fulan]'s court." ${ }^{\prime 61}$ The French officer's official role in the courts was supposed to be restricted to that of a supervisor overseeing deliberations, judgments, order in the courtroom, and record keeping. However, it appears that in practice he

\footnotetext{
${ }^{60}$ See also, for the Middle Atlas courts, Amina Aouchar, Colonisation et Campagne Berbère au Maroc (Casablanca: Afrique Orient, 2002), pt. II, ch. 3.

${ }^{61}$ Unfortunately, I have lost my reference to this quotation. Ayt means tribe. Fulan is a generic name, meaning roughly "so-and-so." There were important exceptions to this generalization, including Tashelhit-speaking Captain Ropars, who headed the Igherm military post from 19491954. See K. E. Hoffman, "Purity and Contamination," 724.
} 
played a role in the rulings, and his presence also served as a reminder that jail time awaited parties who challenged the court's authority.

In regards to written judicial activities of the tribal assemblies, Resident General Lyautey wrote that "given that the Berber language is not written," special dockets needed to be created: one for land and inheritance, a second for assorted deeds, a third for the assembly's deliberations, and a fourth for a record of judgments rendered by the council either directly, or by the arbitrator to be consulted if so proposed by the parties. Lyautey instructed, "These dockets will be kept in the French language, by civil servants, the jama ' $a$ secretaries, who will also play the role of clerk." In summarizing the policy to be carried out in the courts, Lyautey noted that it "shows, in any case, the Protectorate's attention to having a Berber policy that is clearly defined by avoiding the Arabization of Berbers against their will (à leur corps defendant) and in trying to embed our influence among them through our language."62

In the Igherm and Ait Abdallah Native Affairs posts in the 1930s to 1950s, civil cases were kept in French, while criminal cases were kept in French if heard before the local amghar in the tribal penal court or in Arabic if heard by the qadi. The local amghar kept a docket in Arabic of civil cases introduced to the courts and another of criminal matters, although these dockets often lack basic information about cases such as dates and sentences. The customary court secretary kept the four dockets in French prescribed by Lyautey as well as a docket summarizing criminal cases in French, with the attention given to detail depending on staffing needs and the secretary or commanding officer's inclination. ${ }^{63}$ Agreeing with Lyautey's principle, Izard said that keeping courts records in French would ensure the greatest clarity of meaning. ${ }^{64}$ The sole inconvenience was that Berbers complained that their parties could not verify the written copy of the act they received once they left court; the literate villagers, primarily talibs, read only Arabic. Some courts issued verdicts to both parties in both French and Arabic. But Izard wrote that bilingual records should be a provisional measure at best, not a permanent solution. Using Arabic and relying on talibs for translation opened up possibilities for ambiguities and subtleties in the verdicts that religious scholars would intentionally write into the texts. ${ }^{65}$ Despite such ideological concerns, the bilingual, dual-sided summaries of judgments proved to be popular. The practice became

\footnotetext{
62 I. M. Lyautey, "Où en est la question berbère au Maroc," unpublished 1923 report, in CADN Maroc DAI 580, 8.

63 This description is based on both my own field research with the customary court registers from Igherm and Ait Abdallah, and from the procès-verbal of the passage de consignes between Lt. Ropars and Capt. Haguenin, of 20 February 1948, in SHAT 3H 2094, dossier 3.

64 For a discussion of the "clarity" of French, see Pierre Swiggers, "Ideology and the 'Clarity' of French,” in J. E. Joseph and T. J. Taylor, Ideologies of Language (New York: Routledge, 1990), $112-30$.

65 Commandant Izard, "Etude sur l'organisation des Tribunaux Coutumiers," Bureau des Affaires Indigènes, unpublished 1930 report, in CADN Maroc DAI 455, doc. 69.
} 
widespread enough to warrant discussion between Native Affairs and military officers and their supervisors about the best means for archiving these documents, given their unanticipated but highly practical form.

Native Affairs officers relied on religiously trained local men for a variety of reasons. As Montagne remarked in 1924, "There is no longer to be found in this region of the South a hamlet without a mosque or a community without a talib." ${ }^{, 66}$ In the eastern Anti-Atlas mountains, where the Native Affairs officers tended to learn Tashelhit and sometimes written Arabic as well, the local fqih often served as a resource for learning and understanding customary law and for assessing the character of legal parties. This appears to have been a rare situation, however, for in many regions French officers rarely had adequate familiarity with either written Arabic or spoken Berber. Despite pay and advancement incentives, few Native Affairs officers learned Berber, and some were outright hostile to the idea since learning it would do nothing to advance their careers. Yet even in posts where officers clearly did master Berber, as evidenced in their handwritten notes and periodic performance reviews by their superiors, religiously trained men were invaluable not only as translators and interpreters, but as legal experts with close familiarity with local family genealogies, reputations, land holdings, land use, and land boundaries. When a talib served as scribe, he recorded the basic facts of the case in Arabic or, if the court secretary understood Arabic better than Berber, he translated the Berber oral proceedings into Arabic. In so doing he often analyzed Arabic language documents, especially land deeds and genealogies. The secretary then recorded the case claim and verdict in French in the appropriate docket. More often than acting directly as a scribe, however, the talib, whether as part of or adjunct to the judiciary council, conducted investigations into the disputes and advised French officers as to the validity of competing claims. It is hard to say with certainty whether the Arabic that the talib spoke with the Native Affairs officers was colloquial Arabic or classical fusha, or possibly more of a pidgin language involving both and some form of French and/or Berber. In the eastern Anti-Atlas, it seems likely that the talib often spoke Tashelhit in court, so long as the officer understood it.

Lt. de Laforcade, in a study of legal "deeds in customary lands," stressed the unofficial but pervasive law-making power of the village talib, who often had deep knowledge of local legal codes. ${ }^{67}$ In this way the talib served as mediator between customary and Islamic law. He was arguably a key figure not only in the linguistic Arabization of the population but also in its religious and juridical Islamization. It is highly likely that the latter process was already underway in the pre-Protectorate period, but it surely accelerated within the morass of

${ }^{66}$ Montagne, "Le régime juridique des tribus du sud marocain," 326.

${ }^{67}$ Lt. de Laforcade, "Etude sur les actes en pays de coutume," unpublished 1941 report, in CADN Maroc DAI 455, doc. 53, and SHAT 3H 2073, fol. 2, doc. 1. 
Protectorate paperwork. ${ }^{68}$ Moreover, Native Affairs officers themselves were inadvertently agents of Arabization given their widespread and often unreflective use of Arabic in the Berberophone countryside. ${ }^{69}$

Before the Protectorate, disputes were moderated by an assembly of local men under customary law, with the talib acting as notary and providing other social and spiritual services such as healing through incantations, spells, and prayers. Many Protectorate officials saw in the fqih a threat to their efforts to keep Arabic language and orthodox Islam at bay. Lieutenant de vaisseau Robert Montagne in 1927 defended their use and argued that southern Moroccan tribes were accustomed to turning to the "country fqihs or simple tolbas" and that introducing qadis (Islamic judges) "would entail nothing but inconveniences." 70 Apart from the extent to which religious specialists were represented on customary court assemblies, and regardless of concerns over their alleged Arabizing desires, the fqih was often the local customary law specialist. This was made clear in a 1939 note d'instruction from Resident General Nouguès, "relating to the interim judicial organization of Berber tribes of Agadir and the Draa who are not endowed with a qadi [Islamic judge]." The note reminded Native Affairs officers that "the word 'fqih' should not deceive: in the majority of cases this refers to men who have an inkling of shari 'a, but of a very special shari a heavily influenced by and almost indistinguishable from local "urf."71

Some French authorities were deeply disturbed that the Protectorate had to rely so heavily on Muslim religious scholars serving as clerks, translators, and transcribers, much as they had in West Africa. ${ }^{72}$ While some saw their participation on the judicial councils as necessary given their prestige with local populations, others feared they would surreptitiously encourage a shift away from customary law. Yet authorities stopped short of following the lead of French officials in West Africa where, in a 1911 attempt to curb linguistic Arabization and religious Islamization, Arabic writing had been banned from all court and other official records and replaced by French. ${ }^{73}$ Instead, in Morocco French officials debated the merits of translating court documents into unofficial Arabic versions as a supplement to the official French documents. This was a dangerous trend, as Captain Ayard remarked in a 1929 directive to bureau heads in three southern Berber areas, because "without

${ }^{68}$ I am grateful to Clark Lombardi for bringing this possibility to my attention. Such a process certainly merits further investigation, although it is difficult to research and trace historically.

69 This is discussed in El Qadery, "La 'science sociale,", 19-20.

70 Robert Montagne, "Organisation sociale et politique des tribus berbères indépendantes," Revue des Etudes Islamiques 2 (1927): 223-47.

71 CADN Maroc DI 730.

72 Richard Roberts, Litigants and Household: African Disputes and Colonial Courts in the French Soudan 1895-1912 (Portsmouth: Heinemann, 2005), 65-66, and 88-90.

73 Alice L. Conklin, A Mission to Civilize: The Republic Idea of Empire in France and West Africa, 1895-1930 (Stanford: Stanford University Press, 1997), 133. 
exaggeration, we can say that six out of ten cases of rebellion and discontent in the tribes are caused by the fuqaha." 74 The fuqaha felt too secure in the mountains, Ayard wrote; they declared themselves Arabs "even when they originated from the Sahara or the Sous and were consequently of Berber origins." The fqih "poses as a champion of Islam, speaks immediately of bringing people back to the straight path;" he tended to show Berbers that they were ignorant (mécréants), and that "if they don't listen to him," he fears for their "salvation in eternity."75 Despite administrators' attitudes vis-à-vis the local population, these French were often sufficiently competent in Arabic to transmit orders between the Native Affairs office and the qayd, and between the qayd and his khalifa-s (sheriffs). Intercessors tended to be fuqaha and clerks, and a good proportion of them throughout Morocco were natives of the Sous area. In tribes with customary courts, the fqih played the less formal role of arbiter in contrast to the judge in Islamic courts. ${ }^{76}$ These activities further increased both the reliance on and prestige of spoken vernacular Arabic language in the Berber countryside.

\section{The Scope of the Courts}

In 1938, approximately two million Berber Moroccans were governed by custom. For civil matters, there were 145 customary trial courts, in principle one per tribe, although in the Anti-Atlas commonly three or four tribes shared a court. Ninety-eight of these were legally recognized by ministerial decree, with the others still in a trial period in recently "pacified" zones. Under the strict surveillance of the French authorities, these courts functioned as notaries and quasi-legislative bodies. While each jurisdiction adjudicated according to the particular customs of the local Berber groups, varying from one tribe to another, they drew on precedent which, as the Commission reported, was "often in deep antagonism with the rules of shari"a (especially in terms of inheritance and diya or blood price)."77 While the customary courts oversaw property, inheritance, civil, commercial, and personal statute cases among those Berber groups following customary law, all of these areas were divided, in groups following Islamic law, between qadis on the one hand, whose sole role was legal, and pashas or qayds on the other, who exercised legal and also political and administrative powers. The auxiliary secretaries, or clerks, numbered 104. We see from these numbers that some customary courts did not enjoy the luxury of a clerk. The discrepancy did not reflect the still unofficial status of customary courts in the newly pacified

\footnotetext{
74 CADN Maroc DAI 441.

75 Méraud, Histoire des A. I., 179.

76 Ibid., 180.

77 Commission Guernut, "Organisation \& fonctionnement." See also Hart on the diya in "The Penal Code."
} 
lands, since even into the early 1950s Native Affairs officers in the Taroudant region, first under direction from Marrakesh then from Agadir, pleaded incessantly in letters to the resident general to send them more clerks, or else issue credits that would allow them to hire their own.

Six customary appeals courts were created by ministerial decree on 15 September 1934, along with a policy change that sent all penal matters before the local Islamic judge (qadi). In many instances, in practice, penal cases were heard by the tribe, with each tribe or group of tribes using a set shaykh whose court dockets were kept in Arabic. They mainly heard cases of corruption and bribery, refusal to obey orders by Native Affairs officers or their Moroccan representatives such as the local amghar or muqaddem, battery, and occasionally rape, adultery, and murder. All of these crimes were punishable by prison sentences ranging from three months to two years. This is striking because, as Handaine recently pointed out, Berber customary law tended rather consistently to require criminals to pay fines to their tribe rather than imposing the physical punishments stipulated in Islamic law. ${ }^{78}$ The Igherm court dockets indicate that during 'am lbun (literally "the year of rations") between 1940 and 1943, another common punishment for criminal convictions was the withholding of one to three months worth of sugar rations. There was some overlap in the types of cases heard by customary and shaykh courts, and this was allowed when one of the parties insisted on being heard before the shaykh by declaring during the course of the customary court trial that he or she would only be judged by shari $a$ law. ${ }^{79}$ To do this, even Berber monolingual parties would declare in Arabic the phrase "ana b-allahu $b$-shari ' $a$," meaning approximately, "I am in God's justice." ${ }^{80}$ While the investigation by judiciary council members into the parties' claims was often extensive in customary courts, this does not appear to have been the case for shaykh cases for which the rules of evidence were reduced and the shaykh alone adjudicated. This left ample room for parties to influence the outcome through bribes or personal reputation, with sometimes devastating results for defendants. For instance, one woman from the Igherm area who was accused of sexual relations outside marriage was sentenced to two years imprisonment based on villagers' testimonies that repeated hearsay and rumor about an

\footnotetext{
${ }^{78}$ Mohammed Handaine, "Le Droit coutumier et les législations au Maroc: Approche historique," in Organisation Tamaynut, ed., Le Droit Coutumier et les législations au Maroc (Rabat: Organisation Tamaynut, 2007), 61.

${ }_{79}$ Ahmed Arehmouch, Izerfan Imazighen: Droits coutumiers amazigh (Rabat, 2001), 105-6, in Aboulkacem-Afulay El Khatir, "Droit coutumier amazigh face aux processus d'institution et de mise en place de la législation nationale au Maroc," in Organisation Tamaynut, ed., Le Droit Coutumier et les législations au Maroc (Rabat: Organisation Tamaynut, 2007), 97, n. 5.

${ }^{80}$ This does not have the religious connotation usually associated with the word shari $a$. Robert Aspinion, Contribution à l'étude du droit coutumier berbère Marocain (Etude sur les coutumes des tribus zayanes) (Casablanca: Editions A. Moynier, 1937), 15.
} 
affair no one had personally witnessed. The woman's alleged lover was sentenced to only three months in prison.

In addition to their judicial function, the customary courts had unofficial, quasi-legislative attributes, according to the unsigned Guernut report, which said that they "define[d], interpret[ed] and codif[ied] custom which is rarely written and evolves over time and under the influence of social factors. The stages of this evolution are marked, since our intervention, by deliberations of the customary assemblies, that are now written down, that point out the gaps or unclear points of their custom, and at other times usages that have become outdated or no longer respond to recognized needs." In places where customary law applied, appeals were handled by qayds or tribal chiefs. The Penal Customary Section, which was an autonomous organ of the Haut Tribunal Cherifen, had jurisdiction over crimes, correctional appeals, and infractions (délits) committed by native chiefs. ${ }^{81}$

Lest these customary courts seem like archaic anachronisms, it is important to note how much rural residents used them. Table 1 charts their use in 1935 and 1937. To understand customary court usage from a more local perspective, we can consider the following statistics from the Igherm post for the threemonth period of 21 December 1937 to 20 March 1938. The Igherm circumscription had thirty-six thousand residents (with an average of three children per household). Within this population, 217 cases were introduced in twenty court sessions, of which 120 were resolved and 132 remained ongoing. From these hearings 394 deeds were drawn up.

Why did rural people use the customary courts so much? Izard saw the reason as self-evident: plaintiffs and defendants were judged according to their own laws and by fellow tribesmen, and they appreciated the value, clarity, and speed of verdicts that French authority claimed to ensure. Indeed, French officials and scholars argued that if les indigènes used the courts, then they endorsed the use of customary law. We can approach this question in another manner, however, if we presume that customary law is always the "outcome of historical struggles between native elites and their colonial or postcolonial overlords," 82 even if in communities like those of rural Berbers the elite-commoner distinction is not very pronounced. The question of authority immediately emerges, for Berbers arguably appealed to the courts through their assemblies for not just financial compensation for others' wrongdoings, but also moral recognition. Whereas the French system retained the judicial assembly composition that had been used less formally in the pre-Protectorate era, it no longer rotated individuals onto the assembly, a process that had

81 Commission Guernut, "Organisation \& fonctionnement."

82 June Starr and Jane F. Collier, "Introduction: Dialogues in Legal Anthropology," in J. Starr and J. F. Collier, eds., History and Power in the Study of Law (Ithaca: Cornell University Press, 1989), 8-9. 
TABLE 1.

Customary Court Usage in Morocco, 1935-1937.

\begin{tabular}{lrr}
\hline \hline & 1935 & 1937 \\
\hline CIVIL Justice & & \\
$\begin{array}{l}\text { Customary Trial Courts } \\
\text { Judgments rendered }\end{array}$ & 34,000 & 43,000 \\
Misc. deeds drawn up & 65,000 & 75,000 \\
$\begin{array}{l}\text { Customary Appeals Courts } \\
\text { Judgments rendered }\end{array}$ & 207 & 205 \\
CRIMINAL JusticE & & \\
Cases Referred by the & & \\
$\quad$ Customary Criminal Section & 57 & 124 \\
Cases heard & 6 & 11 \\
Appeals heard & 6 & \\
\hline \hline
\end{tabular}

Source: CAOM Guernut 37; unsigned 1938 report, probably by Berenger.

allowed all male household heads alternating responsibilities. Instead, the French handpicked assembly members and screened them for insubordination and "xenophobia" (anti-colonial tendencies), thus ensuring compliance with Protectorate principles. As occurred in other colonial courts, such as those of Tanzania, ${ }^{83}$ this heavy-handed intervention in an allegedly native institution often led to rifts between assembly members and laypeople.

Rural Moroccans also used these courts because they had no choice regarding certain matters, like estate division and land transfers. However, there were alternative means of dispute resolution in certain common types of cases such as boundary disputes. Courts were often a last resort after the parties tried informal arbitration by local highly respected men, outside of the auspices of Protectorate institutions. Ahmed Cassimi described to me how, as a child in the 1940 s, he served tea to the parties assembled before his father, whose arbitration skills were highly sought after. ${ }^{84}$ Indeed, the early customary court dockets often note, in cases where the parties had agreed to a compromise after presenting their sides of the dispute, that "amicable settlements are the best settlements.", 85

${ }^{83}$ Sally Falk Moore, "History," 277-301.

${ }^{84}$ Personal communication, 2009. Georges Marcy similarly claims that Berbers rarely resorted to seeking out the advice of a council for legal issues and disputes. "Le Problème du Droit Coutumier Berbère," Revue Algérienne, Tunisienne et Marocaine de législation et de jurisprudence (1954 [1939]): 22-24.

${ }_{85}$ The phrase "Attendu en droit que les arrangements à l'amiable sont considérés comme les meilleurs jugements" ("Amicable settlements are considered the best rulings") is commonly noted in Igherm and Ait Abdallah courts dockets. See, for example, the docket of Tribunal 
Customary or common law is by its nature malleable, and yet the customary courts endeavored to codify it to the extent that it suited French purposes. ${ }^{86}$ Surdon compared the early-twentieth-century Moroccan situation to that of eighteenth-century France, where custom varied from one province to another, parenthetically noting, "Just before the revolution there were sixty general customs and three hundred particular customs."

As with custom elsewhere, it is oral and is transmitted verbally from one generation to the next. The elders' memory is loyal and sure, but Berber society is divided into innumerable clans and custom breaks down in certain cases when a trial concerns men of opposing clans. In other circumstances, custom is modified and one side acts as though it is applying modified custom whereas their adversaries insist on applying ancestral habits [appliquer le mos majorum].... This was also done [in France] before and the parties had recourse in such cases to an inquest of collaborative witnesses [enquête par turbes] to repair a questionable point in the custom. The assembly members who live among the tribe tend to undergo all the fluctuations in opinion that result from coexistence and the interminable struggle between clans. This also brings about juridical sessions that are very animated, under the inspection of authorities who are there to prevent arguments and to ensure that fair justice is distributed to all. ${ }^{87}$

Certain facts had to be established for each deed: the names of the village, fraction, tribe, residence, and assembly members witnessing the contract. ${ }^{88}$ But beyond that, in terms of the law applied and the precedents invoked to sustain it, there was wide variation.

\section{LANGUAGE OF AUTHORITY IN THE COURT}

The legal administrative paperwork contains ample linguistic directives prescribing proper lexicon and indicating language ideologies governing the production of good communication; terms were to be carefully selected, and the quantity of verbiage was equally important. ${ }^{89}$ Picardat issued a metalinguistic directive that warned against the use of judicial terms analogous to those of French courts, since "as they would not always be judiciously used they generally will not be applicable and will not best represent the spirit of whatever

\footnotetext{
Coutumier I (Igherm), Registre de jugements, 1952-1953, case 51 (1952), n. 23bis. When parties agreed to a settlement, the docket commonly noted that the case had been settled "à l'amiable" ("by mutual consent").

${ }^{86}$ Similarly the British officially discouraged altering customary law in Africa: "Interference with native customary law, which may be relied on to adapt itself to changing circumstances, is much to be deprecated." F. D. Lugard, The Dual Mandate in British Tropical Africa (London: Blackwood, 1965 [1922]), 312, in J. S. Read and H. F. Morris, eds., Indirect Rule and the Search for Justice (Oxford: Clarendon Press, 1972), 167.

${ }_{87}$ Georges Surdon, "Une séance de Djemaa judiciare en pays de coutume berbère."

88 Captain Margin of Fes summarized and circulated these minimal pieces of information needed for customary court records; see CADN Maroc DAI 580.

89 Hoffman, "Purity and Contamination," 735-36.
} 
is under evaluation." Moreover, "a brief and precise statement will always have the advantage of being understood more quickly by everyone." 90

If some Native Affairs officers were arguably overly involved in their courts' proceedings, others were too detached. As court problems compounded, their effectiveness diminished, especially after World War II. By April 1944, Philippe Boniface, Director of Native Affairs in Rabat, wrote a pointed note to the Chef de Commandement of the Agadir region with instructions to distribute it to the region's annex heads: "It has come to the attention of this department that in certain branches the authorities do not entirely and efficiently monitor the customary tribunals. Sessions are often left to the court secretary. I respectfully request that you remain vigilant to assure that the supervision of customary courts be personally ensured and maintained with all the care expected of an agent of the authorities. The authorities must never lose sight of the fundamental political interest attached to the smooth operation of Berber legal institutions." 91

In Igherm, when the staff changed yet again, the post went into decline. The Igherm Native Affairs annex director was targeted directly by Lt. Col. Ferront, head of Taroudant Native Affairs bureau, in a letter dated 19 November 1946. Problems were chronic, and personnel were few and overworked. "During a recent visit," he wrote, "I noted a slacking off in the oversight of the [Igherm] annex's customary courts." Among the problems apparent from the court dockets were the following: The supervising officer for the court was unfamiliar with custom and simply followed the debates, trying to understand and learn. ${ }^{92}$ Verdicts were rendered in each court by the most influential fqih of the court and the court secretary. The legal rules that were applied were those of shari 'a. And finally, the judges responsible for supervising the tribe were never supervised, even while collecting testimonies, and they took advantage of their position to extract advantages for themselves.

The Native Affairs director scolded: "It is time to put your clerk to work. He is very able [étoffé] and will be able to catch up [est à meme de combler ce retard]." Then, acknowledging his own reliance on the commander's knowledge, he requested, "You will please inform me if there has been a constant decrease in custom and as exactly as possible what remains of custom in the

90 Capitaine Picardat, "Contribution à un guide de la justice berbère (coutumes chleuhs)," 1938, in CADN Maroc DAI 454, doc. 44.

91 SHAT 3H 2073.

92 This unfortunate lack of familiarity with local judicial codes was supposed to be avoided in colonial India through a 1 January 1800 law that stipulated that no civil servant would be appointed before demonstrating familiarity with local laws, regulations, and several languages, "the knowledge of which is required for the due discharge of the respective function of such offices." The seminary in which languages were initially taught expanded to a college. The Indian scholars it employed "were engaged in an extraordinary burst of scholarly, literary and pedagogical activities" to make materials available for students to read and write Hindustani given what officials widely perceived was a disastrous reliance on local assistants. See Cohn, "The Command of Language," 306-9. 
legal rules applied and procedure used by the courts in our annex." 93 The allegations suggested that the Native Affairs officer had lost control of his Berber customary court; locals were using it as they wished, even when this meant applying Islamic law, much to the consternation of the French.

\section{CONCLUSION}

French attempts to impose legal pluralism, with distinct zones of Islamic law and Berber customary law, fueled the emergence of a transformed, hierarchical arrangement of legal systems, with Islamic and Berber codes ostensibly juxtaposed in patchwork fashion but in fact more interwoven than Protectorate authorities cared to acknowledge. As Starr and Collier argue, we should not consider legal pluralism to connote "equality that misrepresents the asymmetrical power relations that inhere in the coexistence of multiple legal orders." In the case of the Islamic and Berber legal orders, the lack of equality results from the fact that "legal ideas and processes maintained by subordinated groups are constrained in ways that the legal orders of dominant groups are not." Islamic law under the Protectorate remained off-limits to a European power whose treaty with the sultan ensured the protection of religious institutions and beliefs. Since the French could not alter Islamic law, they set out instead to curb its spread and its influence outside of key centers of political and religious power. It was through the idiom of religious law, in part, that nationalists gained momentum and endeavored to rally support. In this respect, we can consider the various legal orders in place not "as closed cultural systems that one group can impose on another, but rather as 'codes,' discourses, and languages in which people pursue their varying and often antagonistic interests." 94

The mixed legal system in place in the Moroccan hinterlands was further challenged when one party followed customary law and the other Islamic law. Hypothetical questions became pressing ones. Should a given case be heard according to the law in use in the place where the transgression occurred? Should Islamic law necessarily take precedence over customary law? Or should some compromise between the legal traditions be attempted, and if so, who would act as judges or arbitrators? The issue arose most commonly among tribesmen who emigrated to towns or cities, in marketplace disputes, within mixed marriages, and in cases of theft and cases of land transfer. ${ }^{95}$ This

93 See SHAT 3H 2073, dossier 90 A1, Affaires berbères-justice coutumière: Textes légaux et circulaires 1938-1939, "Note pour le Chef d'Annexe d'Irherm," no. 297/C/Tt; cl. 30/A.I.

94 Starr and Collier, "Introduction," 9.

95 In this, French policy differed from an established principle of law in the British Empire that held "that a Hindu or a Muhammadan carries his personal law with him wherever he goes," as one Hindu representative to the Legislative Council of Madras explained in regards to the regulation of marriage among Indians in Fiji; Kelly, "Fear of Culture," 375. Principles guiding such difficult legal situations were more clearly established in Algeria. See Morand, Etudes de droit musulman algérien, $140-47$. 
practical matter raised another legal philosophical question: was the law to be applied according to principles of individual justice, or according to the interests of groups? These issues were taken up by both French legal scholars and Native Affairs officers who were responsible for overseeing the customary courts.

Over a twenty-five-year period, hundreds of thousands of Moroccans took their complaints to the customary courts, and the written documents produced during the Protectorate era provide the basis for legitimate claims today. What these courts declared mattered in ways that shaped people's lives and fortunes across a large portion of rural Morocco. The Arab nationalist narrative that groups 'urf with inauthenticity, jahiliya (pre-Islamic ignorance), and complicity with French colonialism shapes how many laypeople render this institution in their social history, and the institution remains highly, symbolically charged. But despite the official judicial unification at Independence, vestiges of customary law remain in Morocco, and today they are simply considered "custom" that unofficially regulates many aspects of rural life, including agriculture and pastoralism, resource allocation, and local-level decision making. Other matters, such as a divorced woman's right to request compensation for her labor toward the conjugal home (Ar. al kadu al sia ya; Tash. tighrad), have witnessed a revival and are now incorporated into Article 49 of the Mudawana (family status code) that governs all Moroccans, regardless of ethnicity. Far from being a "dead letter," " $u r f$ remains today an important judicial resource not only for rural communities but also for the Moroccan state.

96 Hart, "The Penal Code," 55. 